\title{
Accounting
}

\section{The effect of strategic management accounting on business performance of sugar enterprises in Vietnam}

\author{
Lan Anh Dang ${ }^{a}$, Thi Minh Hue Le ${ }^{a^{*}}$, Thi Hong Le ${ }^{\mathrm{b}}$ and Thi Bich Thu Pham
}

${ }^{a}$ Lecturer, Faculty of Economics and Business Administration, Hong Duc University, Vietnam

${ }^{b}$ Lecturer, Faculty of Economics and Business Administration, Hong Duc University, Vietnam

\section{H R O N I C L E}

Article history:

Received: January 15, 2021

Received in revised format:

January 282021

Accepted: February 24, 2021

Available online:

February 24, 2021

Keywords:

Strategic Management Accounting

Business Performance

Sugar Companies in Vietnam

\section{A B S T R A C T}

\begin{abstract}
This study aims to examine the relationship between selected contingent factors of Strategic Management Accounting including Costing; Planning; control and performance measurements; Strategic decision - making; Competitor Accounting; Customers Accounting and Business Performance in the context of Sugar Companies in Vietnam. By applying the quantitative data obtained from managers and accountants of the companies, the study provides some evidence supporting the effect of contingent factors on the extent of Strategic Management Accounting usage. The results of the study draw conclusions regarding the effect of Strategic Management Accounting on the Business Performance of the companies as well. From which, the authors suggest some directions to enhance Strategic Management Accounting usage in the companies and solutions to increase their business performance efficiency.
\end{abstract}

\section{Introduction}

The liberalization and globalization of the business world in recent years and the faster speed of technological changes have affected the role of the management accountants. Chenhall (2003) highlighted the important role of management accountants in providing information for strategic decision-making and controlling by using their knowledge and experience. There are two main stages in the strategic decision - making process, they are creating and implementing the strategy to increase firm efficiency. To conduct this vital function, the relevant information is necessary not only for management accountants but also for managers. Most companies in Vietnam have just focused on Traditional Management Accounting (TMA) which is not suitable for updating dynamic information. A new information system is needed to fit to the new dynamic and global environment. Strategic Management Accounting (SMA) is a new technique to meet contemporary challenges of recent modern companies. Guilding et al. (2000) stated that SMA can create considerable value by providing more relevant information required for making decisions of managers. SMA could also help to increase their company's profitability and efficiency by using modern management accounting methods such as Activity Based Costing (ABC) and Activity Based Management (ABM); SMA is one of useful techniques to enhance the positive performance of companies. Sugar is one of the important industries in Vietnam, they contribute billions for the government budget every year. According to a report from the Vietnam Sugar Association, in the 2018/2019 crop, Vietnam has 36 sugar enterprises operating, including 7 Limited liability companies (Foreign-Invested Enterprises), 29 Joint stock companies. In particular, 11 sugar enterprises in the North, 14 sugar enterprises

\footnotetext{
* Corresponding author.

E-mail address: lethiminhhue@hdu.edu.vn (K. S. AljT.M.H. Le)
} 
1086

in the Central - Highlands, 6 sugar enterprises in the Southeast and 5 in the Mekong Delta. In the 2018-2019 crop, these enterprises had a volume of pressed sugar of about 14 million tons, with 1,3 million tons of sugar produced. In the general context of the world sugar industry, Vietnam's sugar industry is gradually entering a period of saturation. Domestic sugar consumption increased at an average rate of about 24\%, from 0.64 million tons/ year in the period of 1994-1998 to 1,6 million tons/ year in the period of 2014-2019. The growth is decreasing gradually over time. According to forecasts of The Organization for Economic Co-operation and Development (OECD) and the Food and Agriculture Organization (FAO) of the United Nations, domestic sugar consumption in Vietnam will reach about 1,8 million tons by 2023, the average consumption is estimated at about 1,76 million tons/ year for the 5-year period from 2019 - 2023.

Vietnam's sugar industry is currently under competitive pressure from the ASEAN Free Trade Agreement (ATIGA). From January $1^{\text {st }} 2020$, Article 20 of the ATIGA has been implemented on the sugar product from ASEAN countries to Vietnamese market with a tax rate of only $0-5 \%$. Besides, domestic sugar enterprises are worried about losing the domestic market due to the pressure from cheap Thai illegal sugar spilling into our country. In the 2017/2018 crop, the illegal sugar output is estimated to reach over $33 \%$ of the national sugar market share, and Thailand becomes the main competitor for domestic sugar enterprises. In order to maintain its position in this context, Vietnam Sugar Enterprises are forced to solve the problem of lowering production costs, as well as the orientation for development of after-sugar products such as alcohol and fertilizer, molasses, water extracted from sugarcane, renewable energy-electricity from bagasse, from which to enhance their Business Performance. However, based on general surveys, the companies have good Financial Accounting systems, but Management Accouting has not been really focused. Previous studies conducted on most companies in Vietnam in general and Sugar Companies Vietnam in particular showed that Traditional Management Accounting (TMA) still has been used for decision - making purposes. However, TMA is highly quantitative and internally focused, meanwhile the changing manufacturing environment and competition makes it difficult for TMA to provide dynamic information for businesses; TMA leads managers in the companies to limit their focus to operational issues and not to focus on external aspects relating to competitors, products quality, and customers. Such information was previously deemed important and sufficient for planning, decision making, and control. The SMA has been examined by managers in the companies, however the SMA application has still remained backwards. The author reckoned the need of studying the influence of SMA on Business Performance (BP), in order to determine the effect of contingent factors of SMA to BP of Sugar Companies in Vietnam. From which, the author suggests some directions for enhancing SMA usage in the companies and making orientation of increasing their Business Performance efficiency.

\section{Literature Review}

Simmonds $(1981,1982)$ has firstly defined SMA as an analysis of Management Accounting data including information of the business and its competitors, with the purpose of developing and monitoring business strategy. However, Simmonds pointed that SMA focuses on competitor information more. Bromwich and Bhimani $(1989,1994)$ defined SMA as the provision and analysis of financial information on the company's product markets, competitors' costs, cost structures and the monitoring of strategies of the enterprise and its competitors over a period of time. According to Bromwich, SMA is simply collecting data about the competitive advantage or value added of the business, and of the competitors as well to evaluate the benefits of the organization over a long-term. Roslender and Hart (2002, 2003) defined SMA as a generic approach to accounting for strategic positioning, attempting to integrate insights from management accounting and marketing management within a strategic management framework. Guilding et al. (2000) described the criteria for considering particular accounting techniques as "strategic." The main characteristics of SMA as a strategy imply a long-term future orientation period and an externally focused perspective. Guilding et al. (2000) also gathered 12 SMA techniques from the literature, then Cravens and Guilding (2001) added another 3 techniques. After that, Cadez and Guilding (2008) gave 16 SMA techniques from previous works, and they classified these techniques into 5 broad categories. They are Costing; Planning, control and performance measurements; Strategic decision-making; Competitor Accounting; and Customers Accounting.

In addition, Chenhall and Langfield-Smith (1998) found a positive correlation between SMA usage and business performance by examining how the combination of management techniques and management accounting practices enhance business performance. Cadez and Guilding (2008) examined the effect of strategic choices, market orientation, and company size on two distinct SMA dimensions and the mediating effect of SMA on company performance. They found that SMA usage contributes to positive financial and non-financial organizational performance. Baines and Langfield-Smith (2003) found that SMA usage has positive effects on manufacturing enterprises. In this study, the author uses measurable items for the Business Performance (BP) which was adopted by Tippins and Sohi (2003), they are Return on investment, Customer satisfaction, Customer retention, Development of new products, Firm growth, Profitability, and Sales growth. 
Table 1

Management accounting techniques exhibiting strategic orientation

\begin{tabular}{|c|c|c|c|}
\hline $\begin{array}{l}\text { SMA technique } \\
\text { categories }\end{array}$ & SMA techniques & Explanation & Source \\
\hline \multirow{5}{*}{ Costing } & 1. Target costing & $\begin{array}{l}\text { A method used during product and process design that involves estimating } \\
\text { a cost calculated by subtracting a desired profit margin from an estimated } \\
\text { (or market-based) price to arrive at a desired production, engineering, or } \\
\text { marketing cost. The product is then designed to meet that cost. }\end{array}$ & $\begin{array}{l}\text { Monden and Hamada, } \\
\text { 1991; Cooper and } \\
\text { Slagmulder, } 1999\end{array}$ \\
\hline & 2. Quality costing & $\begin{array}{l}\text { Quality costs are those costs associated with the creation, identification, } \\
\text { repair and prevention of defects. These can be classified into three } \\
\text { categories: prevention, appraisal, and internal and external failure costs. } \\
\text { Cost of quality reports are produced for the purpose of directing } \\
\text { management attention to prioritize quality problems. }\end{array}$ & $\begin{array}{l}\text { Heagy, 1991; Belohlav, } \\
1993\end{array}$ \\
\hline & 3.Life-cycle costing & $\begin{array}{l}\text { The appraisal of costs based on the length of stages of a product or } \\
\text { service's life. These stages may include design, introduction, growth, } \\
\text { maturity, decline and eventually abandonment. }\end{array}$ & $\begin{array}{l}\text { Czyzewski and Hull, } \\
\text { 1991; Shields and Young, } \\
\text { 1991; Dunk, } 2004\end{array}$ \\
\hline & 4.Value-chain costing & $\begin{array}{l}\text { An activity-based approach where costs are allocated to activities required } \\
\text { to design, procure, produce, market, distribute, and service a product or } \\
\text { service. }\end{array}$ & $\begin{array}{l}\text { Hergert and Morris, 1989; } \\
\text { Shank and Govindarajan, } \\
\text { 1992; Dekker, } 2003\end{array}$ \\
\hline & 5.Attribute costing & $\begin{array}{l}\text { The costing of specific product attributes that appeal to customers. } \\
\text { Attributes that may be costed include: operating performance variables; } \\
\text { reliability, warranty arrangements; the degree of finish and trim; } \\
\text { assurance of supply; and after sales service. }\end{array}$ & $\begin{array}{l}\text { Bromwich \& Bhimani, } \\
\text { 1989, 1994; Roslender \& } \\
\text { Hart, } 2003\end{array}$ \\
\hline \multirow{4}{*}{$\begin{array}{l}\text { Planning, control } \\
\text { and performance } \\
\text { measurements }\end{array}$} & $\begin{array}{l}\text { 1.Integrated performance } \\
\text { measurement }\end{array}$ & $\begin{array}{l}\text { A measurement system which focuses typically on acquiring performance } \\
\text { knowledge based on customer requirements and may encompass non- } \\
\text { financial measures. This measure involves departments monitoring those } \\
\text { factors which are critical to securing customer satisfaction. }\end{array}$ & \multirow{2}{*}{$\begin{array}{l}\text { Kaplan and Norton, 1992; } \\
\text { 1996; Ittner et al., 2003; } \\
\text { Libby et al., 2004; } \\
\text { Chenhall, 2005 }\end{array}$} \\
\hline & 2. Budgeting & $\begin{array}{l}\text { Budgeting is the process of creating a plan to spend your money. This } \\
\text { spending plan is called a budget. Creating this spending plan allows you } \\
\text { to determine in advance whether you will have enough money to do the } \\
\text { things you need to do or would like to do. Budgeting is simply balancing } \\
\text { expenses with income. }\end{array}$ & \\
\hline & 3. Benchmarking & The comparison of internal processes to an ideal standard. & $\begin{array}{l}\text { Elnathan et al; 1996, } \\
\text { Brownlie, } 1999\end{array}$ \\
\hline & $\begin{array}{l}\text { 2.Integrated performance } \\
\text { measurement }\end{array}$ & $\begin{array}{l}\text { A measurement system which focuses typically on acquiring performance } \\
\text { knowledge based on customer requirements and may encompass non- } \\
\text { financial measures. This measure involves departments monitoring those } \\
\text { factors which are critical to securing customer satisfaction. }\end{array}$ & $\begin{array}{l}\text { Kaplan and Norton, 1992; } \\
\text { 1996; Ittner et al., 2003; } \\
\text { Libby et al., 2004; } \\
\text { Chenhall, 2005 }\end{array}$ \\
\hline \multirow{3}{*}{$\begin{array}{l}\text { Strategic decision- } \\
\text { making }\end{array}$} & 2. Strategic pricing & $\begin{array}{l}\text { The analysis of strategic factors in the pricing decision process. These } \\
\text { factors may include: competitor price reaction, elasticity, market growth, } \\
\text { economies of scale, and experience. }\end{array}$ & $\begin{array}{l}\text { Simmonds, 1982; } \\
\text { Rickwood et al., } 1990\end{array}$ \\
\hline & 3. Brand valuation & $\begin{array}{l}\text { The financial valuation of a brand through the assessment of brand } \\
\text { strength factors such as: leadership, stability, market, internationality, } \\
\text { trend, support, and protection combined with historical brand profits. }\end{array}$ & $\begin{array}{l}\text { Guilding, 1992; Cravens } \\
\text { and Guilding, } 1999\end{array}$ \\
\hline & 1. Strategic costing & $\begin{array}{l}\text { The use of cost data based on strategic and marketing information to } \\
\text { develop and identify superior strategies that will produce a sustainable } \\
\text { competitive advantage. }\end{array}$ & $\begin{array}{l}\text { Shank and Govindarajan, } \\
\text { 1988; } \\
\text { 1993; Shank, } 1996\end{array}$ \\
\hline \multirow{3}{*}{$\begin{array}{l}\text { Competitor } \\
\text { Accounting }\end{array}$} & $\begin{array}{l}\text { 1.Competitive position } \\
\text { monitoring }\end{array}$ & $\begin{array}{l}\text { The analysis of competitor positions within the industry by assessing and } \\
\text { monitoring trends in competitor sales, market share, volume, unit costs, } \\
\text { and return on sales. This information can provide a basis for the } \\
\text { assessment of a competitor's market strategy. }\end{array}$ & $\begin{array}{l}\text { Simmonds, 1986; } \\
\text { Rangone, } 1997\end{array}$ \\
\hline & $\begin{array}{l}\text { 2.Competitor cost } \\
\text { assessment }\end{array}$ & $\begin{array}{l}\text { The provision of regularly scheduled update estimate of a competitor's } \\
\text { unit cost. }\end{array}$ & $\begin{array}{l}\text { Simmonds, 1982; Jones, } \\
\text { 1988; Bromwich \& } \\
\text { Bhimani, 1989, 1994; } \\
\text { Ward, 1992 }\end{array}$ \\
\hline & $\begin{array}{l}\text { 3.Competitor } \\
\text { performance appraisal }\end{array}$ & $\begin{array}{l}\text { The numerical analysis of a competitor's published statements as a part of } \\
\text { an assessment of a competitor's key sources of competitive advantage. }\end{array}$ & Moon and Bates, 1993 \\
\hline \multirow{3}{*}{$\begin{array}{l}\text { Customers } \\
\text { Accounting }\end{array}$} & $\begin{array}{l}\text { 1.Lifetime customer } \\
\text { profitability analysis }\end{array}$ & $\begin{array}{l}\text { This involves extending the time horizon for customer profitability } \\
\text { analysis to include future years. The practice focuses on all anticipated } \\
\text { future revenue streams and costs involved in servicing a particular } \\
\text { customer. }\end{array}$ & $\begin{array}{l}\text { Foster and Gupta, 1994; } \\
\quad \text { Jacob, 1994) }\end{array}$ \\
\hline & $\begin{array}{l}\text { 2.Valuation of } \\
\text { Customers as Assets }\end{array}$ & $\begin{array}{l}\text { The technique refers to the calculation of the value of customers to the } \\
\text { company. For example, this could be undertaken by computing the present } \\
\text { value of all future profit streams attributable to a particular customer. }\end{array}$ & $\begin{array}{l}\text { Slater and Narver, 1994; } \\
\text { Foster and Gupta, } 1996\end{array}$ \\
\hline & $\begin{array}{l}\text { 3.Customer profitability } \\
\text { analysis }\end{array}$ & $\begin{array}{l}\text { This involves calculating profit earned from a specific customer. The } \\
\text { profit calculation is based on costs and sales that can be traced to a } \\
\text { particular customer. This technique is sometimes referred to as "customer } \\
\text { account profitability". }\end{array}$ & $\begin{array}{c}\text { Bellis-Jones, 1989; Ward, } \\
1992\end{array}$ \\
\hline
\end{tabular}




\section{Methodology}

\subsection{Research Models and Hypotheses}

In this study, we aim to evaluate the impact of SME on Business Performance in Sugar Companies in Vietnam. With reference to SME components, Business Performance scale adopted by previous studies (Guilding et al., 2000; Cadez \& Guilding, 2008; Cravens \& Guilding 2001) and the actual conditions of Sugar Companies in Vietnam, the authors selected 17 scales that constitute 5 components which are represent 01 independent factor (SME):

(1) Costing (CO) factor is described by CO1-CO5 including: Target costing, Quality costing, Life-cycle costing, Value chain costing, and Attribute costing.

(2) Planning, control and performance measurement (PL) factor is described by PL1-PL3 including: Performance measurement, Budgeting, and Benchmarking Integrated.

(3) Strategic decision-making (STRA) factor is described by STRA1-STRA3 including: Strategic pricing, Brand valuation, and Strategic costing.

(4) Competitor Accounting (COM) factor is described by COM1-COM3 including: Competitive position monitoring, Competitor cost assessment, and Competitor performance appraisal.

(5) Customer Accounting (CUS) factor is described by CUS1-CUS3 including: Lifetime customer profitability analysis, Valuation of Customers as Assets, and Customer profitability analysis.

And 01 dependent factor:

(6) Business Performance (BP) factor is described by BP1-BP7: Return on investment, Customer satisfaction, Customer retention, Development of new products, Firm growth, Profitability, and Sales growth (Tippins \& Sohi, 2003)

The research model is established on the assumptions that factors (1), (2), (3), (4), (5) are represented by SME; and they have direct impact on (6). The proposed research model as shown in Fig. 1.

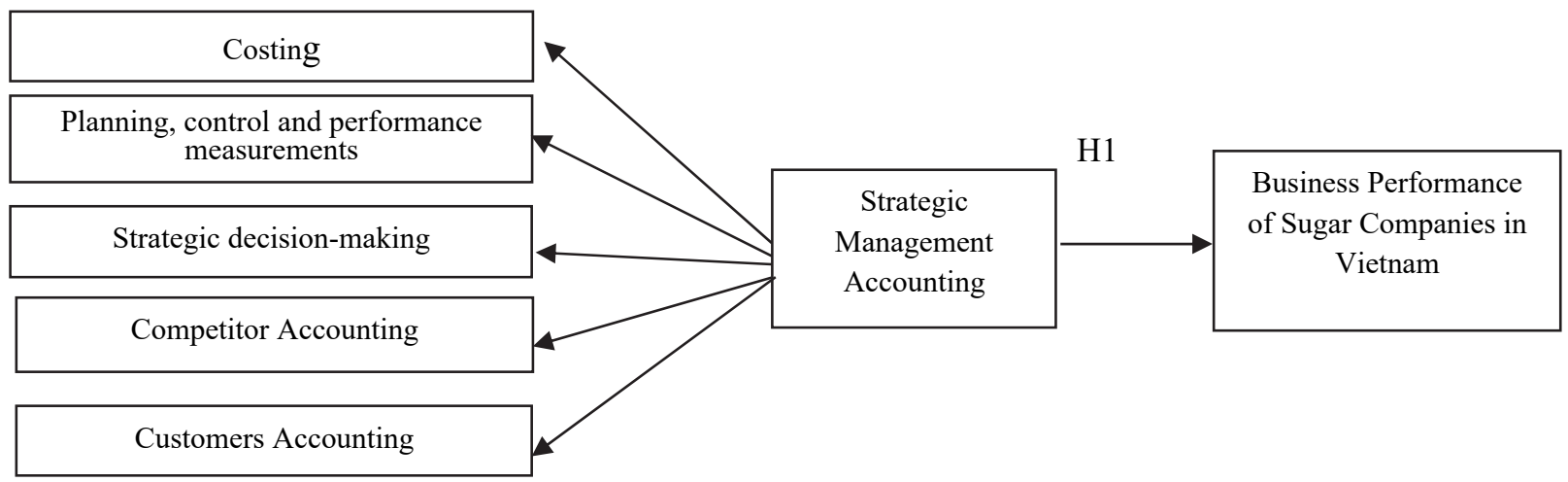

Fig. 1. Research model

Source: (Guilding et al., 2000; Cadez \& Guilding, 2008; Cravens \& Guilding 2001; Tippins and Sohi 2003)

\section{Research Hypotheses:}

(H1): Strategic Management Accounting (SMA) positively affects the Business Performance of Sugar Companies in Vietnam.

\subsection{Research Method}

Research methodology was conducted through 2 steps: Qualitative research and quantitative research.

Qualitative research was conducted with a sample of 20 managers and accountants in the Sugars Companies in Vietnam to explore Factors perceiving the EMAI and examining the Business Performance (BP) of the Sugars Companies in Vietnam. Qualitative research results help the authors establish quantitative measurement tools.

Quantitative research was conducted through 2 phases.

In phase 1, the authors experimented on a small group to detect errors in the questionnaire. In phase 2 , the authors conducted a revised questionnaire. 
The survey was conducted in December 2019. According to the study of Hair et al. (1998), if the sample size is around 100, the loading factor standard must be greater than 0.5. Bollen (1986) proposed the ratio of 5 observations per estimated parameter in the multivariate analysis. In the research, there are 24 variable observations, so the minimum sample size should be equal to $24 * 5=$ 120 samples. The study has a sample size of 350 managers and accountants in the Sugars Companies in Vietnam, which can meet the requirements and be generalizable, representative of the total study; The total number of valid questionnaires collected and processed was 306 questionnaires.

Hair et al. (1998) also recommends that study subjects were asked to answer questions on a 5-level Likert scale (from 1 "the worst" to 5 "the best"). Questionnaires answered by respondents were the main tool for collecting data. The author performs Exploratory Factor Analysis (EFA), Confirmatory Factor Analysis (CFA), and Linear Structural Modeling (SEM) using SPSS.20 software in combination with AMOS.20. Accreditation was done through the following steps:

- Preliminary evaluation on the measurement scale and reliability of variables by Cronbach's Alpha and Factor Loading by the Exploratory Factor Analysis (EFA).

- The CFA method was used to test critical models by examining univariate, multivariate, convergent and discriminated values of concepts.

- From the CFA results, to construct and validate the fit of the research model through the SEM model, to assess the impact of independent variables on the dependent variable.

- Measurement scale of research concepts: Including 24 observed variables (Corresponding to 05 components which present 01 independent factor and 1 dependent factor)

- Sample survey statistics: The number of questionnaires sent was 350; 306 valid votes were used for this analysis. The survey subjects were managers and accountants in the Sugars Companies in Vietnam.

\section{Results}

\subsection{Descriptive Statistics}

The study has a sample size of 306 managers and accountants, resulting in a total of 350 valid survey questionnaires collected and processed. Demographic information of the observed sample is presented in Fig. 2.

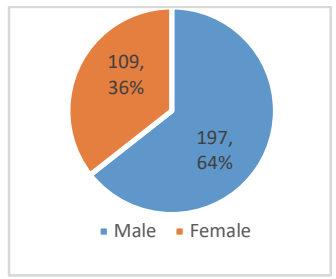

Gender

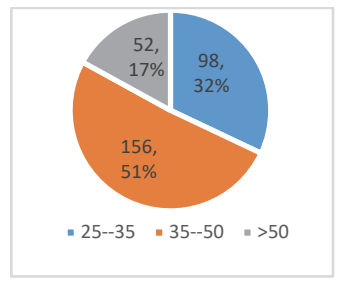

Age

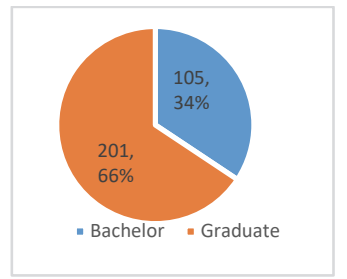

Education

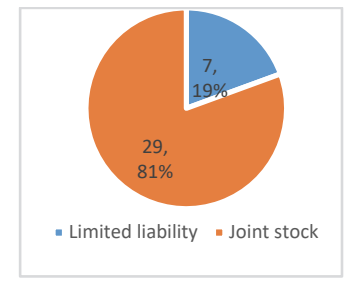

Ownership

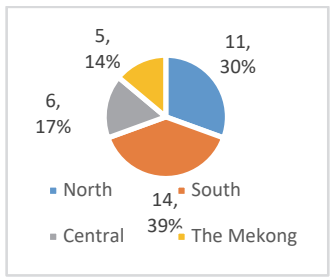

Region

Fig. 2. Description of demographic characteristics of the surveyed sample

(Source: The author's data analysis)

\subsection{Scale reliability test results and exploratory factor analysis}

The total number of valid questionnaires collected was 306 samples. The author used SPSS.20 software to process 24 variables, all variables are good for the next analysis with the Cronbach's Alpha $>0.6$ and Corrected Item-Total Correlation $>0.4$.

\subsection{Analysis of Exploratory Factor}

According to Anderson and Gerbing (1988), Principal Axis Factoring was used with Promax rotation and factor loading coefficients $\geq 0.5$ to incorporate remaining variables into Exploratory Factor Analysis (EFA) model for the purposes of scale validation. We have the resultant KMO coefficient $=0,883>0,5$; Bartlett's Test statistics are 3491.746 with significance level of $0,000<0,05$; Cumulative of Variance is $75.072 \%(>50 \%)$. This proves that the analytical data is perfectly relevant. Thus, all factor loading coefficients are greater than 0,5 ; explained variance is greater than $50 \%$, the remaining 24 observed variables are grouped exactly as the original scale. 
Table 2

Scale Reliability Test Results

\begin{tabular}{|c|c|c|c|}
\hline Factors & Variables & $\begin{array}{l}\text { Corrected Item- } \\
\text { Total Correlation }\end{array}$ & $\begin{array}{c}\text { Cronbach's Alpha } \\
\text { if Item Deleted }\end{array}$ \\
\hline \multicolumn{4}{|c|}{ CO. Cronbach' alpha $=0.771$} \\
\hline \multirow{5}{*}{ Costing (CO) } & CO1: Target costing & 0.500 & 0.745 \\
\hline & CO2: Quality costing & 0.549 & 0.729 \\
\hline & CO3:Life-cycle costing & 0.546 & 0.729 \\
\hline & CO4: Value chain costing & 0.613 & 0.703 \\
\hline & CO5: Attribute costing & 0.543 & 0.737 \\
\hline \multirow{4}{*}{$\begin{array}{c}\text { Customers Accounting } \\
\text { (CUS) }\end{array}$} & \multicolumn{2}{|c|}{ CUS. Cronbach' alpha $=0.714$} & \\
\hline & CUS1: Lifetime customer & 0.683 & 0.683 \\
\hline & CUS2: Valuation of Customers as Assets & 0.604 & 0.604 \\
\hline & CUS3: Customer profitability analysis & 0.586 & 0.686 \\
\hline \multirow{4}{*}{$\begin{array}{l}\text { Planning. control and } \\
\text { performance }(\mathrm{PL})\end{array}$} & \multicolumn{2}{|c|}{ PL. Cronbach' alpha $=0.699$} & \\
\hline & PL1: Performance measurement & 0.510 & 0.616 \\
\hline & PL2: Budgeting & 0.531 & 0.693 \\
\hline & PL3: Benchmarking Integrated & 0.513 & 0.610 \\
\hline \multirow{4}{*}{$\begin{array}{l}\text { Strategic decision- } \\
\text { making (STRA) }\end{array}$} & \multicolumn{2}{|c|}{ STRA. Cronbach' alpha $=0.933$} & \\
\hline & STRA1: Strategic pricing & 0.900 & 0.873 \\
\hline & STRA2: Brand valuation & 0.882 & 0.888 \\
\hline & STRA3: Strategic costing & 0.809 & 0.947 \\
\hline \multicolumn{3}{|c|}{ COM. Cronbach' alpha $=0.840$} & \\
\hline \multirow{3}{*}{$\begin{array}{c}\text { Competitor } \\
\text { Accounting (COM) }\end{array}$} & COM1: Competitive position monitoring & 0.686 & 0.797 \\
\hline & COM2: Competitor cost assessment & 0.738 & 0.745 \\
\hline & COM3: Competitor performance appraisal & 0.691 & 0.791 \\
\hline \multirow{8}{*}{$\begin{array}{c}\text { Business Performance } \\
\text { (BP) }\end{array}$} & \multicolumn{2}{|c|}{ BP. Cronbach' alpha $=0.861$} & \\
\hline & BP1: Return on investment & 0.588 & 0.848 \\
\hline & BP2: Customer satisfaction & 0.558 & 0.853 \\
\hline & BP3: Customer retention & 0.586 & 0.853 \\
\hline & BP4: Development of new products & 0.656 & 0.839 \\
\hline & BP5: Firm growth & 0.720 & 0.832 \\
\hline & BP6: Profitability & 0.721 & 0.830 \\
\hline & BP7: Sales growth & 0.645 & 0.840 \\
\hline
\end{tabular}

Table 3

The results of KMO and Bartlett's test

Kaiser-Meyer-Olkin Measure of Sampling Adequacy.

Bartlett's Test of Sphericity

It is shown in the EFA results the following factors:

Factor 1: includes the observed variables BP1-BP7 and is named "Business Performance" (BP).

Factor 2: includes observed variables STRA1-STRA3 and is named "Strategic decision-making" (STRA).

Factor 3: includes observed variables CO1-C05 and is named "Costing" (CO).

Factor 4: includes observed variables COM1-COM3 and is named “Competitor Accounting” (COM).

Factor 5: includes observed variables CUS1-CUS3 and is named "Customers Accounting" (CUS).

Factor 6: includes observed variables PL1-PL3 and is named "Planning, control and performance measurement" (PL).

After EFA exploratory analysis, it can be seen that the model have no difference from the research model, no observed variable is excluded from the study variables. There is no new factor group as Table 4.

\subsection{Analysis of Confirmatory Factor}

The critical model of research concepts is shown in Fig. 3 The critical model is a model of established factors that are freely interrelated. CFI $=0,947$, TLI $=0,939$ are all greater than 0,9 (Bentler \& Bonelt, 1980) and RMSEA $=0,049<0.8($ Steiger, 1990). The factor weights of each observed variable are greater than 0.5 , so the model can be considered convergent. 
Table 4

Exploratory factor analysis matrix

\begin{tabular}{|c|c|c|c|c|c|c|}
\hline & \multicolumn{6}{|c|}{ Factor } \\
\hline & 1 & 2 & 3 & 4 & 5 & 6 \\
\hline BP6 & 0.858 & & & & & \\
\hline BP5 & 0.776 & & & & & \\
\hline BP4 & 0.722 & & & & & \\
\hline BP3 & 0.689 & & & & & \\
\hline BP7 & 0.645 & & & & & \\
\hline BP1 & 0.596 & & & & & \\
\hline BP2 & 0.515 & & & & & \\
\hline STRA1 & & 0.998 & & & & \\
\hline STRA2 & & 0.923 & & & & \\
\hline STRA3 & & 0.797 & & & & \\
\hline $\mathrm{CO} 4$ & & & 0.694 & & & \\
\hline $\mathrm{CO} 3$ & & & 0.656 & & & \\
\hline $\mathrm{CO} 2$ & & & 0.646 & & & \\
\hline $\mathrm{CO} 1$ & & & 0.642 & & & \\
\hline $\mathrm{CO} 5$ & & & 0.535 & & & \\
\hline COM2 & & & & 0.885 & & \\
\hline COM1 & & & & 0.671 & & \\
\hline COM3 & & & & 0.664 & & \\
\hline CUS3 & & & & & 0.761 & \\
\hline CUS2 & & & & & 0.646 & \\
\hline CUS1 & & & & & 0.577 & \\
\hline PL2 & & & & & & 0.713 \\
\hline PL3 & & & & & & 0.617 \\
\hline PL1 & & & & & & 0.556 \\
\hline
\end{tabular}

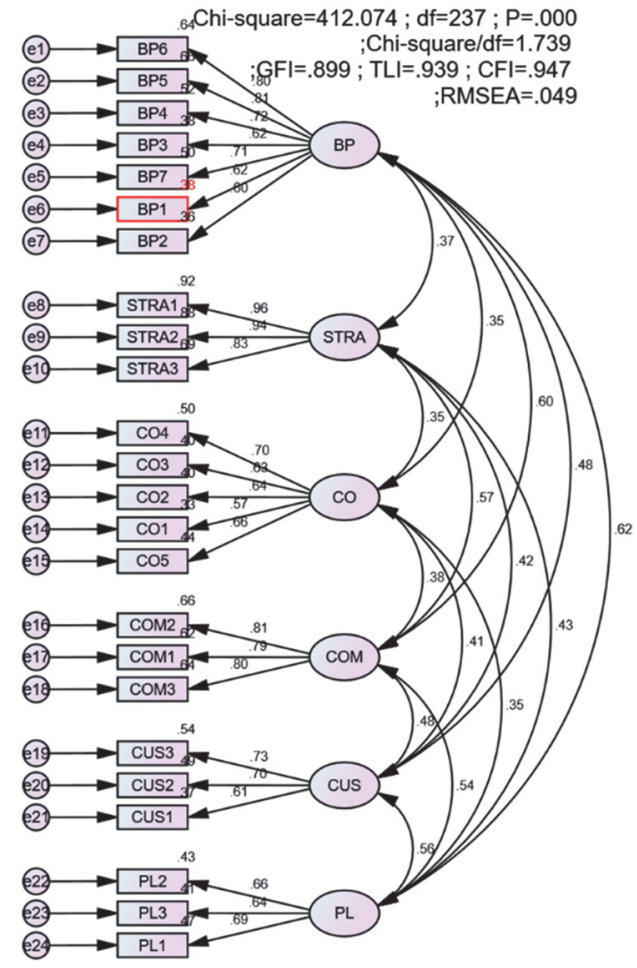

Fig. 3. CFA analysis results for the critical model

(Source: The author's data analysis) 
1092

Results of the analysis showed that: Correlation coefficients were less than 1, covariance testing and correlation between pairs of variables were statistically significant $(\mathrm{p}<0.05$ value, Table 5$)$. This implies that the factors in the model can be distinguished.

Table 5

Computable Rreliability Coefficients and Variance of Factors in the Model

\begin{tabular}{|c|c|c|c|c|c|c|c|}
\hline & & & Estimate & S.E. & C.R. & $\mathrm{P}$ & Label \\
\hline ВР6 & $\leftarrow$ & BP & 1.000 & & & & \\
\hline BP5 & $\leftarrow$ & $\mathrm{BP}$ & 0.908 & 0.060 & 15.133 & $* * *$ & \\
\hline BP4 & $\leftarrow$ & BP & 0.863 & 0.066 & 13.127 & $* * *$ & \\
\hline BP3 & $\leftarrow$ & $\mathrm{BP}$ & 1.009 & .092 & 10.988 & $* * *$ & \\
\hline BP7 & $\leftarrow$ & BP & 0.913 & 0.071 & 12.871 & $* * *$ & \\
\hline BP1 & $\leftarrow$ & BP & 0.803 & 0.073 & 10.989 & $* * *$ & \\
\hline BP2 & $\leftarrow$ & BP & 0.846 & .080 & 10.559 & $* * *$ & \\
\hline STRA1 & $\leftarrow$ & STRA & 1.000 & & & & \\
\hline STRA2 & $\leftarrow$ & STRA & 0.975 & 0.031 & 31.580 & $* * *$ & \\
\hline STRA3 & $\leftarrow$ & STRA & 0.925 & 0.041 & 22.668 & $* * *$ & \\
\hline $\mathrm{CO} 4$ & $\leftarrow$ & $\mathrm{CO}$ & 1.000 & & & & \\
\hline $\mathrm{CO} 3$ & $\leftarrow$ & $\mathrm{CO}$ & 0.751 & 0.082 & 9.119 & $* * *$ & \\
\hline $\mathrm{CO} 2$ & $\leftarrow$ & $\mathrm{CO}$ & 0.739 & 0.080 & 9.192 & $* * *$ & \\
\hline $\mathrm{CO} 1$ & $\leftarrow$ & $\mathrm{CO}$ & 0.600 & 0.071 & 8.426 & $* * *$ & \\
\hline $\mathrm{CO} 5$ & $\leftarrow$ & $\mathrm{CO}$ & 1.051 & 0.111 & 9.491 & $* * *$ & \\
\hline COM2 & $\leftarrow$ & COM & 1.000 & & & & \\
\hline COM1 & $\leftarrow$ & COM & 1.016 & 0.072 & 14.112 & $* * *$ & \\
\hline COM3 & $\leftarrow$ & COM & 0.954 & 0.067 & 14.256 & $* * *$ & \\
\hline CUS3 & $\leftarrow$ & CUS & 1.000 & & & & \\
\hline CUS2 & $\leftarrow$ & CUS & 0.814 & 0.087 & 9.307 & $* * *$ & \\
\hline CUS1 & $\leftarrow$ & CUS & 0.824 & 0.097 & 8.523 & $* * *$ & \\
\hline PL2 & $\leftarrow$ & PL & 1.000 & & & & \\
\hline PL3 & $\leftarrow$ & PL & 0.844 & 0.100 & 8.423 & $* * *$ & \\
\hline PL1 & $\leftarrow$ & PL & 0.867 & 0.099 & 8.740 & $* * *$ & \\
\hline
\end{tabular}

\subsection{Structural Equation Modeling (SEM)}

The study uses the SEM to assess the relevance of the research model and test the relationships in the initial model. The results of the SEM analysis of the model with $\mathrm{df}=457$, Chi-square $=907.007$ with p-value $=0.000<0.05$, Chi-square $/ \mathrm{df}=1.985<3$, $\mathrm{CFI}=0.919, \mathrm{TLI}=0,912$; RMSEA $=0.57<0.8$ should confirm that the pattern consistent with market data (Fig. 4).

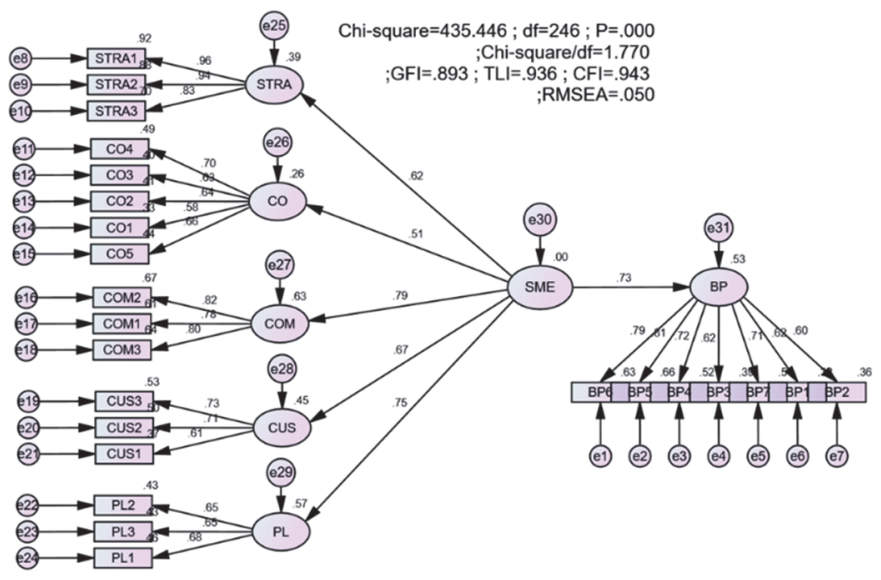

Fig. 4. Standardized Structural Equation Modeling (SEM)

(Source: The author's data analysis) 
The SEM result shows that the relationships between Strategic Management Accounting (SMA) and Business Performance are acceptable $(\mathrm{p}<0.05)$. The hypotheses $\mathbf{H}_{1}$ are accepted (value of $\mathrm{p}<0.05$ ), in which the Strategic Management Accounting (SMA) strongly affects the Business Performance of Sugar Companies in Vietnam. This result is also consistent with the actual conditions of the Companies.

Table 6

Hypothesis Testing Results

\begin{tabular}{|c|c|c|c|c|c|c|c|}
\hline & & & Standard Estimates & S.E. & C.R. & $\mathbf{P}$ & Noted \\
\hline STRA & $\leftarrow$ & SME & 0.621 & & & & Accepted \\
\hline $\mathrm{CO}$ & $\leftarrow$ & SME & 0.509 & 0.111 & 5.955 & $* * *$ & Accepted \\
\hline $\mathrm{COM}$ & $\leftarrow$ & SME & 0.794 & 0.133 & 8.527 & $* * *$ & Accepted \\
\hline CUS & $\leftarrow$ & SME & 0.668 & 0.103 & 7.086 & $* * *$ & Accepted \\
\hline PL & $\leftarrow$ & SME & 0.753 & 0.128 & 7.158 & $* * *$ & Accepted \\
\hline $\mathrm{BP}$ & $\leftarrow$ & SME & 0.621 & 0.105 & 8.165 & $* * *$ & Accepted \\
\hline
\end{tabular}

Results of the causal relationship between the components in the research model in Table 6 with $p<0.05$ confirmed that the factors including, Planning; Strategic decision-making; Competitor Accounting; Costing, Competitor Accounting; Customers Accounting, Control and performance measurements has a causal relationship with Strategic Management Accounting. At the same time, Strategic Management Accounting has the positive impact on Business Performance of Sugar Companies in Vietnam. Strategic Management Accounting (SMA) is measured by the scales of costing, planning, control and performance measurements; Strategic decision-making; Competitor Accounting; and Customers Accounting. When these factors are better, the SMA is evaluated better as well. Based on the results of survey and data processing, the authors propose Sugar Companies in Vietnam to improve the effectiveness of costing, planning, control and performance measurements; Strategic decisionmaking; Competitor Accounting; and Customers Accounting; thereby improving the efficiency of SMA and Enhancing Business Performance.

\section{Discussion and Conclusions}

Based on the results of survey and data processing, the authors propose Sugar Companies in Vietnam to improve the effectiveness of Costing; Planning, control and performance measurements; Strategic decision-making; Competitor Accounting; and Customers Accounting; thereby improving the efficiency of SMA and Enhancing Business Performance. Specifically, for Costing jobs, companies should focus on the application and improving Attribute costing, Quality costing, Target costing and Value chain costing. For planning, control and performance measurements; the companies need to improve the process of budgeting, benchmarking, integrated and performance measurement. For strategic decision-making, companies need to focus on improving the effectiveness of strategic costing, strategic pricing and brand valuation. For Competitor Accounting, the companies need to improve the Competitor cost assessment, Competitive position monitoring and Competitor performance appraisal. And, for Customers Accounting, the companies should focus on Customer Profitability Analysis, Lifetime Customer Profitability Analysis, and Valuation of Customers as Assets. The limitation of this study is that it is only implemented at Sugar Companies in Vietnam, an industry with many differences compared to other areas. Therefore, the research results are somewhat different from other industries in the locality and in the country, so the generalizability is not high. Therefore, there should be extensive research on the scope of other fields. The authors hope that further research will address the limitations of this research.

\section{References}

Anderson, J. C., \& Gerbing, D. W. (1988). Structural equation modeling in practice: A review and recommended two-step approach. Psychological Bulletin, 103(3), 411. https://doi.org/10.1037/0033-2909.103.3.411.

Baines, A., \& Langfield-Smith, K. (2003) Antecedents to management accounting change: a structural equation approach, Accounting, Organizations and Society. https://doi.org/10.1016/S0361-3682(02)00102-2

Bollen, K.A. (1986), Sample Size and Bentler and Bonett's Nonnormed Fit Index, Psychometrika.

Belohlav, J. A. (1993). Quality, strategy, and competitiveness. California Management Review, 35(3), 55-67.

Bellis-Jones, R. (1989). Customer profitability analysis. Management Accounting, 63, 26-28.

Bentler, P. M., \& Bonett, D. G. (1980). Significance tests and goodness of fit in the analysis of covariance structures. Psychological Bulletin, 88(3), 588. https://doi.org/10.1037/0033-2909.88.3.588

Bromwich, M., \& Bhimani, A. (1994). Management accounting: Pathways to progress, Chartered institute of management accountants, London.

Bromwich, M., \& Bhimani, A. (1989), Management Accounting: Evolution Not Revolution. The Chartered Institute of Management Accountants.

Brownlie, D. (1999). Benchmarking your marketing process. Long Range Planning, 32(1), 88-95.

Cadez, S., \& Guilding, C. (2008). An exploratory investigation of an integrated contingency model of strategic management accounting. Accounting, Organizations and Society, 33(7-8), 836-863. https://doi.org/ 10.1016/j.aos.2008.01.003

Cooper, R., \& Slagmulder, R. (1999). Develop profitable new products with target costing. MIT Sloan Management Review, 40(4), 23. 
Chenhall, R. H. (2003). Management control systems design within its organizational context: findings from contingency-based research and directions for the future. Accounting, Organizations and Society, 28(2-3), 127-168.

Chenhall, R. H., \& Langfield-Smith, K. (1998). The relationship between strategic priorities, management techniques and management accounting: an empirical investigation using a systems approach. Accounting, Organizations and Society, 23(3), $243-264$.

Chenhall, R. H. (2005). Integrative strategic performance measurement systems, strategic alignment of manufacturing, learning and strategic outcomes: an exploratory study. Accounting, Organizations and Society, 30(5), 395-422.

Cravens, K. S., \& Guilding, C. (2001). An empirical study of the application of strategic management accounting techniques. Advances in Management Accounting, 10, 95-124.

Czyzewski, A. B., \& Hull, R. P. (1991). Improving profitability with life cycle costing. Journal of Cost Management, 5(2), $20-27$.

Dekker, H. C. (2003). Value chain analysis in interfirm relationships: a field study. Management Accounting Research, 14(1), 1-23.

Dunk, A. S. (2004). Product life cycle cost analysis: the impact of customer profiling, competitive advantage, and quality of IS information. Management Accounting Research, 15(4), 401-414. https://doi.org/ 10.1016/j.mar.2004.04.001

Elnathan, D., Lin, T. W., \& Young, M. S. (1996). Benchmarking and management accounting: a framework for research. Journal of Management Accounting Research, 8, 37- 54.

Foster, G., \& Gupta, M. (1994). Marketing, cost management and management accounting. Journal of Management Accounting Research, 6, 43-77.

Guilding, C., Cravens, K. S., \& Tayles, M. (2000). An international comparison of strategic management accounting practices. Management Accounting Research, 11(1), 113-135. https://doi.org/ 10.1006/mare.1999.0120

Hair, J.F., Black, W.C., Babin, B.J., Anerson, R.E. \& Tatham, R.L. (1998), Multivariate data analysis.

Heagy, C. D. (1991). Determining optimal quality costs by considering cost of lost sales. Journal of Cost Management, 5(3), 64-72.

Hergert, M., \& Morris, D. (1989). Accounting data for value chain analysis. Strategic Management Journal, 10(2), $175-188$.

Ittner, C. D., Larcker, D. F., \& Randall, T. (2003). Performance implications of strategic performance measurement in financial services firms. Accounting, Organizations and Society, 28(7-8), 715-741. https://doi.org/ 10.1016/S0361-3682(03)00033-3

Jacob, R. (1994). Why some customers are more equal than others. Fortune, 130, 215-220.

Jones, L. (1988). Competitor cost analysis at Caterpillar. Strategic Finance, 77, 32-38.

Kaplan, R. S., \& Norton, D. P. (1992). The balanced scorecard: measures that drive performance. Harvard Business Review, 70, 7180.

Libby, T., Salterio, S. E., \& Webb, A. (2004). The balanced scorecard: The effects of assurance and process accountability on managerial judgment. The Accounting Review, 79(4), 1075-1094. https://doi.org/ 10.2308/accr.2004.79.4.1075

Monden, Y., \& Hamada, K. (1991). Target costing and kaizen costing in Japanese automobile companies. Journal of Management Accounting Research, 3(1), 16-34. https://doi.org/10.1142/9781848160385 0005

Moon, P., \& Bates, K. (1993). Core analysis in strategic performance appraisal. Management Accounting Research, 4(2), $139-152$.

Roslender, R., \& Hart, S. J. (2002). Integrating management accounting and marketing in the pursuit of competitive advantage: the case for strategic management accounting. Critical Perspectives on Accounting, 13(2), 255-277.

Roslender, R., \& Hart, S. J. (2003). In search of strategic management accounting: theoretical and field study perspectives. Management Accounting Research, 14(3), 255-279.

Simmonds, K. (1981). Strategic Management Accounting. Review of Management Accounting Research (pp.22-52).

Simmonds, K. (1982). Strategic management accounting for pricing: a case example. Accounting and Business Research, 12(47), 206214.

Shank, J. K. (1996). Analysing technology investments - from NPV to strategic cost management (SCM). Management Accounting Research, 7(2), 185-197.. https://doi.org/ 10.1016/j.bar.2005.10.003

Shank, J. K., \& Govindarajan, V. (1988). Making strategy explicit in cost analysis: a case study. MIT Sloan Management Review, 29(3), 19. https://doi.org/ 10.1007/978-3-319-48454-9 17

Shields, M. D., \& Young, S. M. (1991). Managing product life cycle costs: an organizational model. Journal of Cost Management, $5(3), 39-52$.

Slater, S. F., \& Narver, J. C. (1994). Market orientation, customer value, and superior performance. Business Horizons, 37(2), $22-28$. https://doi.org/ 10.1016/0007-6813(94)90029-9

Rangone, A. (1997). Linking organizational effectiveness, key success factors and performance measures: an analytical framework. Management Accounting Research, 8(2), 207-219.

Rickwood, C. P., Coates, J. B., \& Stacey, R. J. (1990). Stapylton: strategic management accounting to gain competitive advantage. Management Accounting Research, 1(1), 37-49. https://doi.org/ 10.1016/S1044-5005(90)70044-3

Tippins, M. J., \& Sohi, R. S. (2003). IT competency and firm performance: is organizational learning a missing link?. Strategic Management Journal, 24(8), 745-761. http://dx.doi.org/10.1002/smj.337

Ward, K. (1992). Strategic Management Accounting. Oxford: Butterworth-Heineman.

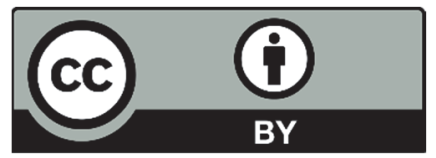

(C) 2021 by the authors; licensee Growing Science, Canada. This is an open access article distributed under the terms and conditions of the Creative Commons Attribution (CC-BY) license (http://creativecommons.org/licenses/by/4.0/). 